UDC 577.22

\title{
Interactome of invadopodia scaffold protein TKS5
}

\author{
S. V. Kropyvko \\ Institute of Molecular Biology and Genetics, NAS of Ukraine \\ 150, Akademika Zabolotnoho Str., Kyiv, Ukraine, 03680 \\ siryl_2000@yahoo.com
}

TKS5 is a scaffold protein that takes part in invadopodia functioning and reactive oxygen species (ROS) production. TKS5 is a critical component of invadopodia as its absence results in the loss of cancer cells ability to form these invasive structures. TKS5 is phosphorylated by SRC kinase and consequently interacts with the membrane phosphatidylinositol phosphates launching the invadopodia formation process. At later stages TKS5 regulates the actin cytoskeleton reorganization and extracellular matrix degradation. TKS5 also regulates the production of ROS, which are the important signal regulators of different cellular functions.

Key w or d s: TKS5, interactome, invadopodia, scaffold protein.

\section{Introduction}

Scaffold proteins play an important role in all cellular processes. These proteins usually do not have enzymatic activity and their main function is the protein complex assembly to provide the coupling of different cellular compartments and processes. This function is realized by a variety of protein-protein and protein-lipid interaction domains such as Phox homology (PX), pleckstrin-homology (PH) domains that bind to different membrane phospholipids [1] or Src-homology 2 and 3 (SH2 and SH3) domains that bind to phosphotyrosine residues $(\mathrm{pY})$ and prolinerich motifs (PxxP) respectively [2]. One of these proteins discovered in 1998 is invadopodia scaffold protein TKS5 (Tyrosine kinase substrate with five SH3 domains) known also as SH3PXD2A [3]. Invadopodia and podosomes are specialized actin-rich cellular structures. They promote the cell migration and invasion together with the extracellular matrix (ECM) degradation which makes them an important research object. The term "podosome" is used to define the structures in normal cells such as osteoclasts, macro- phages, endothelial cells and vessel smooth muscle cells. The term "invadopodium" is used to define the structures of invasive cancer cells. [4].

The key features of podosomes and invadopodia are the F-actin polimerization and ECM degradation. These transient structures are localized at the ventral part of the cellular membrane and contain a multitude of different proteins. They promote cellular adhesion and their proteolytic activity is indispensable for the ECM degradation, which makes them key players in the cell invasion [4]. TKS5 is a key scaffold of invadopodia. In its absence the cells completely lose the ability to form invadopodia [5]. This fact makes TKS5 a potential target for cancer cure $[6,7]$ and one of the central proteins in the investigation of cancer cell invasion.

\section{TKS5 phosphorylation}

TKS5 scaffold protein contains one PX domain, five SH3 domains, proline-rich motifs, and three SRC phosphorylation sites (Fig. 1). TKS5 was discovered as a tyrosine kinase substrate. TKS5 is phosphorylated by SRC tyrosine kinase (Rous sarcoma virus

(C) 2015 S. V. Kropyvko; Published by the Institute of Molecular Biology and Genetics, NAS of Ukraine on behalf of Biopolymers and Cell. This is an Open Access article distributed under the terms of the Creative Commons Attribution License (http://creativecommons.org/licenses/by/4.0/), which permits unrestricted reuse, distribution, and reproduction in any medium, provided the original work is properly cited 
tyrosine kinase), which is a well-known oncogene and one of the key components of invadopodia and podosomes. SRC kinase is indispensable for the invadopodia formation as it phosphorylates (and activates) main proteins of these structures [4]. The tyrosines 552, 557 and 619 of TKS5 are phosphorylated (Fig. 1). As a result of phosphorylation, TKS5 is activated and enters the invadopodia formation process [3]. TKS5 dephosphorylation, therefore its inhibition, is performed by SHP2 (Src homolog domaincontaining phosphatase 2), which inhibits the podosome formation [8]. Besides, the TKS5 activity can be regulated through dimerization. Oikawa et al. have shown the possibility of TKS5 dimerization and proposed a model, according to which TKS5 forms a dimer in inactive state: TKS5/TKS5. Following the induction of invadopodia formation, TKS5 is phosphorylated by SRC kinase, which leads to the dissociation of TKS5/TKS5 dimer, and TKS5 acquires an open conformation that allows it to interact with other proteins, e.g. actin polymerization regulators such as WASP (Wiskott-Aldrich syndrome protein) and GRB2 (growth factor receptor-bound protein 2). The activation and breaking of TKS5/TKS5 dimer may also occur due to the TKS5 interaction with the membrane phosphatidylinositol phosphates that leads to its localization on the invadopodia formation sites where the complex formation begins [9].

\section{Interaction of TKS5 with membrane and involvement in actin cytoskeleton rearrange- ments}

PX domain of TKS5 binds phosphatidylinositol-3,4bisphosphate $\left(\operatorname{PtdIns}(3,4) \mathrm{P}_{2}\right)$ and phosphatidylinositol-3-phosphate (PtdIns3P), that are shown to regulate the actin cortex and cell migration [10]. The interaction of TKS5 with PtdIns $(3,4) \mathrm{P}_{2}$ and PtdIns3P is necessary for the beginning of invadopodia formation [11]. According to some authors, these phospholipids are the markers for the invadopodia formation sites $[12,13]$. A TKS5 mutant lacking the PX domain inhibits the podosome formation [14].

After the TKS5-membrane interaction, the assembly of complexes which induce the membrane protrusion begins. TKS5 may take part in the membrane deformation through the interaction with IRTKS (Insulin receptor tyrosine kinase substrate) - BAR domain-containing protein, which has the membrane

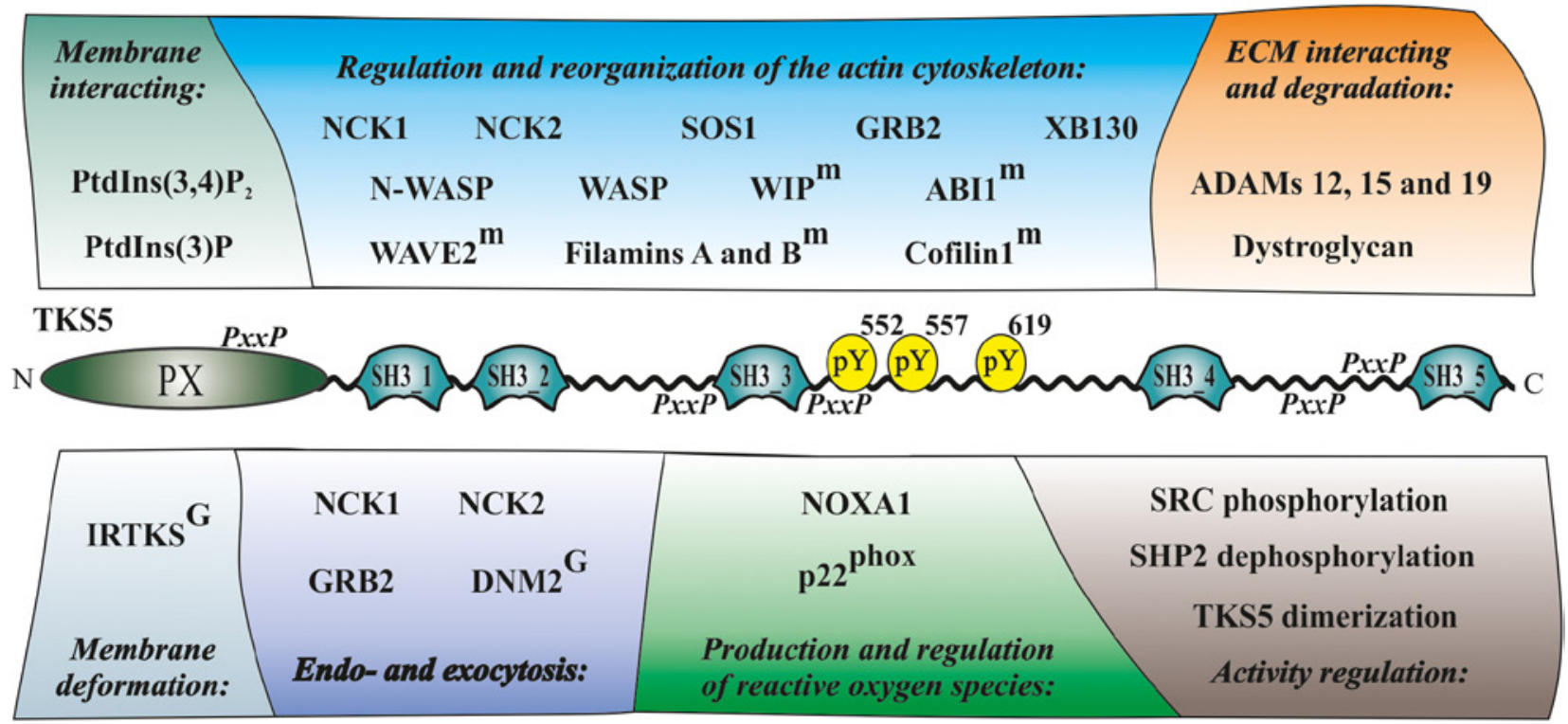

Fig. 1. Schematic presentation of the TKS5 domain structure and its known partners. ${ }^{m}$ - mass spectrometry analysis; ${ }^{\mathrm{G}}-$ GST pulldown assay 
deforming activity [15]. The actin cytoskeleton formation also plays an important role in this process. According to Oser et al., TKS5 and regulator of actin nucleation CTTN1 (cortactin 1) recruitment is the first event in the invadopodia formation [16]. The interaction of CTTN1 with TKS5 was not shown [17], whereas another family member, TKS4 (Tyrosine kinase substrate with four SH3 domains), interacts with CTTN1 and enters the invadopodia formation process at later stages $[4,18]$. However, it was shown that TKS5 recruits CTTN1 together with AFAP-110 (actin filament-associated protein of $110 \mathrm{kDa}$ ) and $\mathrm{p} 190 \mathrm{RhoGAP}$ (p190) to the podosome formation sites [14].

TKS5 interacts with a multitude of other proteins involved in the actin cytoskeleton rearrangements, such as WASP, N-WASP (neural Wiskott-Aldrich syndrome protein) $[9,13]$, guanine nucleotide exchange factor which activates RAS - SOS1 (son of sevenless 1) [19]. It also interacts with the adaptor proteins NCK1 (noncatalytic region of tyrosine kinase 1), NCK2 (noncatalytic region of tyrosine kinase 2), and GRB2, which are implicated in the invadopodia formation through different signaling pathways $[13,17,20]$. Oikawa et al. have shown with a comprehensive mass spectrometry analysis that TKS5 was associated with the actin-regulatory proteins such as WIP (WASP-interacting protein), ABI1 (Abl interactor-1), WAVE2 (WASP family verprolin-homologous protein 2), cofilin 1, filamin A and B and others [9]. TKS4 also interacts with some of these proteins $[18,21,22]$ that may indicate a collaboration of two TKS family members in actin cytoskeleton rearrangements during the invadopodia formation.

\section{TKS5 involvement in interaction and degra- dation of ECM}

An important invadopodia function is an interaction with the ECM and its degradation. TKS5 interacts with ECM through dystroglycan [23], which is a transmembrane adhesion receptor that binds ECM proteins containing laminin $\mathrm{G}$ (LamG) domains, such as laminin, neurexin, and agrin, in a calcium-dependent manner [24]. Dystroglycan consists of $\alpha$ - and $\beta$-subunits and is described as one of the important adhesion proteins in the invadopodia formation [23].

The ECM degradation is realized by different protease families including a metalloprotease family. Its member, MT1MMP (metalloprotease membrane type 1 matrix metalloprotease) also known as MMP14, is a central metalloprotease of invadopodia [4]. ADAM (a disintegrin and metalloprotease) transmembrane proteins form another zinc protease superfamily, which takes part in the ECM degradation during the invadopodia formation, characterized by metalloprotease activities and interaction with the integrin receptor. Some family members interact with different signal transduction proteins through the cytoplasmic domain [25]. Many family members have multiple PxxP motifs in their cytoplasmic domains, which allow the interaction with the SH3 domain-containing proteins. In particular, Abram et al. have shown that TKS5 binds proteases ADAM 12,15 , and 19 [11].

\section{Production and regulation of reactive oxy- gen species (ROS)}

Reactive oxygen species (ROS), such as superoxide $\left(\mathrm{O}_{2}^{-}\right)$and peroxide $\left(\mathrm{H}_{2} \mathrm{O}_{2}\right)$, were first considered as toxic metabolic products [26]. Now it is widely accepted that ROS are important signal regulators of many cellular functions, such as signal transduction, gene expression, cell growth and apoptosis [27]. Additionally, it was revealed that the ROS production increases during oncotransformation and metastasis $[27,28]$. The majority of ROS in the cell are synthesized as a by-product of oxidative phosphorylation in mitochondria or as a result of the NADPH oxidase NOX family functioning. This family includes NOX1-5 (NADPH oxidase 1-5) and DUOX12 (dual oxidase 1-2) and generates the major portion of signal ROS in the cell [4, 29]. SRC-induced ROS production by NOX1 plays an important role in invadopodia formation and ECM degradation [4]. Gianni et al. have shown that TKS5 and TKS4 function as organizers for Nox oxidases and can induce NOX1 and NOX3 activity [30]. This hypothesis is supported by the paper of Diaz et al. where a direct 
interaction of TKS5 with a small transmembrane protein p22 $2^{\text {phox }}$ (CYBA; cytochrome b-245, alpha polypeptide) was shown [29]. This protein functions as a skeleton for the maturing and folding of catalytically active NOX [26, 31]. TKS5 and TKS4 also bind the proline motif of NADPH oxidases activator NOXA1 (NOX activating protein). Moreover, in the case of TKS5/NOXA1 this interaction is indispensable for the Tks5-mediated ROS generation by Nox 1 [32]. The mechanism of ROS influence on the podosome formation is unclear yet. As the TKS family members are obligatory components of invadopodia and podosomes, they might play an exceptional role in the ROS localization to invadopodia, unlike other NOX organizers. Alissa Weaver proposed a model that the SRC-induced ROS production by NOX oxidases in invadopodia is secondary, being a response to the TKS4 and TKS5 phosphorylation by SRC kinase; whereas TKS4 and TKS5, in turn, serve as the organizers and activators of NOX oxidases in invadopodia [27].

\section{Other processes}

The TKS5 participation in other cellular processes is poorly investigated. It may take part in the endocytosis through the interaction with GTPase DNM2 (dynamin 2) [19], which is one of the key components of this process. DNM2 is involved in the invadopodia formation as well [4]. Other TKS5 partner - adaptor GRB2 - also takes part in endo-/exocytosis [33].

Moodley et al. suggest that TKS5, similar to scaffold protein XB130, plays a role in the cell proliferation and cell survival and that the interaction between XB130 and TKS5 appears to be critical for the regulation of SRC-mediated cellular homeostasis [34]. XB130 (also called AFAP1L2, for actin filament associated protein 1 like 2) is an adaptor/scaffold protein involved in many cellular functions, such as the cell survival, cell proliferation, migration, gene and miRNA expression [35].

\section{Acknowledgments}

The author gratefully acknowledges Prof. A. Rynditch and Dr. O. Gubar for critical reading the manuscript.

\section{REFERENCES}

1. Balla T. Inositol-lipid binding motifs: signal integrators through protein-lipid and protein-protein interactions. J Cell Sci. 2005;118(Pt 10):2093-104.

2. Reebye V, Frilling A, Hajitou A, Nicholls JP, Habib NA, Mintz PJ. A perspective on non-catalytic Src homology (SH) adaptor signalling proteins. Cell Signal. 2012;24(2):388-92.

3. Lock P, Abram CL, Gibson T, Courtneidge SA. A new method for isolating tyrosine kinase substrates used to identify fish, an SH3 and PX domain-containing protein, and Src substrate. EMBO J. 1998;17(15):4346-57.

4. Murphy DA, Courtneidge SA. The 'ins' and 'outs' of podosomes and invadopodia: characteristics, formation and function. Nat Rev Mol Cell Biol. 2011;12(7):413-26.

5. Seals DF, Azucena EF Jr, Pass I, Tesfay L, Gordon R, Woodrow M, Resau JH, Courtneidge SA. The adaptor protein $\mathrm{Tks} 5 /$ Fish is required for podosome formation and function, and for the protease-driven invasion of cancer cells. Cancer Cell. 2005;7(2):155-65.

6. Stylli SS, I ST, Kaye AH, Lock P. Prognostic significance of Tks5 expression in gliomas. $J$ Clin Neurosci. 2012;19(3):436-42.

7. Stylli SS, Luwor RB, Kaye AH, I ST, Hovens CM, Lock P. Expression of the adaptor protein Tks5 in human cancer: prognostic potential. Oncol Rep. 2014;32(3):989-1002.

8. Pan YR, Cho KH, Lee HH, Chang ZF, Chen HC. Protein tyrosine phosphatase SHP2 suppresses podosome rosette formation in Src-transformed fibroblasts. $J$ Cell Sci. 2013;126(Pt 2):657-66.

9. Oikawa T, Oyama M, Kozuka-Hata H, Uehara S, Udagawa $N$, Saya H, Matsuo K. Tks5-dependent formation of circumferential podosomes/invadopodia mediates cell-cell fusion. J Cell Biol. 2012;197(4):553-68.

10. Tsujita K, Itoh T. Phosphoinositides in the regulation of actin cortex and cell migration. Biochim Biophys Acta. 2015;1851(6):824-31.

11. Abram CL, Seals DF, Pass I, Salinsky D, Maurer L, Roth TM, Courtneidge SA. The adaptor protein fish associates with members of the ADAMs family and localizes to podosomes of Src-transformed cells. $J$ Biol Chem. 2003;278(19):16844-51.

12. Yamaguchi H, Oikawa T. Membrane lipids in invadopodia and podosomes: key structures for cancer invasion and metastasis. Oncotarget. 2010;1(5):320-8.

13. Oikawa T, Itoh T, Takenawa T. Sequential signals toward podosome formation in NIH-src cells. $J$ Cell Biol. 2008;182(1):157-69.

14. Crimaldi L, Courtneidge SA, Gimona M. Tks5 recruits AFAP-110, p190RhoGAP, and cortactin for podosome formation. Exp Cell Res. 2009;315(15):2581-92.

15. Oikawa T, Matsuo K. Possible role of IRTKS in Tks5-driven osteoclast fusion. Commun Integr Biol. 2012;5(5):511-5. 
Interactome of invadopodia scaffold protein TKS5

16. Oser M, Yamaguchi H, Mader CC, Bravo-Cordero JJ, Arias $M$, Chen X, Desmarais V, van Rheenen J, Koleske AJ, Condeelis $J$. Cortactin regulates cofilin and N-WASp activities to control the stages of invadopodium assembly and maturation. J Cell Biol. 2009;186(4):571-87.

17. Stylli SS, Stacey TT, Verhagen AM, Xu SS, Pass I, Courtneidge $S A$, Lock $P$. Nck adaptor proteins link Tks5 to invadopodia actin regulation and ECM degradation. J Cell Sci. 2009;122(Pt 15):2727-40.

18. Lányi Á, Baráth $M$, Péterfi $Z$, Bogel $G$, Orient A, Simon $T$, Petrovszki E, Kis-Tóth K, Sirokmány G, Rajnavölgyi É, Terhorst $C$, Buday L, Geiszt M. The homolog of the five SH3domain protein (HOFI/SH3PXD2B) regulates lamellipodia formation and cell spreading. PLoS One. 2011;6(8):e23653.

19. Rufer AC, Rumpf J, von Holleben $M$, Beer $S$, Rittinger $K$, Groemping $Y$. Isoform-selective interaction of the adaptor protein Tks5/FISH with Sos1 and dynamins. $J$ Mol Biol. 2009;390(5):939-50.

20. Oser M, Dovas A, Cox D, Condeelis J. Nck1 and Grb2 localization patterns can distinguish invadopodia from podosomes. Eur J Cell Biol. 2011;90(2-3):181-8.

21. Kropyvko $S V$. New partners of TKS4 scaffold protein. Biopolym Cell. 2015; 31(5):395-401.

22. Bisson N, James DA, Ivosev G, Tate SA, Bonner R, Taylor L, Pawson $T$. Selected reaction monitoring mass spectrometry reveals the dynamics of signaling through the GRB2 adaptor. Nat Biotechnol. 2011;29(7):653-8.

23. Thompson O, Kleino I, Crimaldi L, Gimona M, Saksela K, Winder SJ. Dystroglycan, Tks5 and Src mediated assembly of podosomes in myoblasts. PLoS One. 2008;3(11):e3638.

24. Endo T. Dystroglycan glycosylation and its role in alphadystroglycanopathies. Acta Myol. 2007;26(3):165-70.

25. Seals DF, Courtneidge SA. The ADAMs family of metalloproteases: multidomain proteins with multiple functions. Genes Dev. 2003;17(1):7-30.

26. Bedard $K$, Krause $K H$. The NOX family of ROS-generating NADPH oxidases: physiology and pathophysiology. Physiol Rev. 2007;87(1):245-313.

27. Weaver $A M$. Regulation of cancer invasion by reactive oxygen species and Tks family scaffold proteins. Sci Signal. 2009;2(88):pe56.

28. $W u W S$. The signaling mechanism of ROS in tumor progression. Cancer Metastasis Rev. 2006;25(4):695-705.

29. Diaz B, Shani G, Pass I, Anderson D, Quintavalle M, Courtneidge $S A$. Tks5-dependent, nox-mediated generation of reactive oxygen species is necessary for invadopodia formation. Sci Signal. 2009;2(88):ra53.

30. Gianni D, Diaz B, Taulet N, Fowler B, Courtneidge SA, Bokoch $G M$. Novel p47(phox)-related organizers regulate localized NADPH oxidase 1 (Nox1) activity. Sci Signal. 2009;2(88):ra54.

31. Brandes RP, Weissmann $N$, Schröder $K$. Nox family NADPH oxidases: Molecular mechanisms of activation. Free Radic Biol Med. 2014;76:208-26.
32. Gianni D, DerMardirossian C, Bokoch GM. Direct interaction between Tks proteins and the N-terminal proline-rich region (PRR) of NoxA1 mediates Nox1-dependent ROS generation. Eur J Cell Biol. 2011;90(2-3):164-71.

33. Kawada $K$, Upadhyay $G$, Ferandon $S$, Janarthanan $S$, Hall $M$, Vilardaga JP, Yajnik $V$. Cell migration is regulated by platelet-derived growth factor receptor endocytosis. Mol Cell Biol. 2009;29(16):4508-18.

34. Moodley S, Hui Bai X, Kapus A, Yang B, Liu M. XB130/ Tks5 scaffold protein interaction regulates Src-mediated cell proliferation and survival. Mol Biol Cell. 2015;26(24):4492-502.

35. Bai XH, Cho HR, Moodley S, Liu M. XB130-A Novel Adaptor Protein: Gene, Function, and Roles in Tumorigenesis. Scientifica (Cairo). 2014;2014:903014.

\section{Інтерактом скафолдного білка інвадоподій TKS5}

С. В. Кропивко

TKS5 скафолдний білок, який приймає участь у функціонуванні інвадоподій та продукції активних форм кисню (ROS). TKS5 критично важливий компонент інвадоподій оскільки за його відсутності ракові клітини втрачають можливість утворювати ці структури інвазивності. Він фосфорилюється SRC-кіназою в наслідок чого взаємодіє з фосфотидилінозитид фосфатами мембрани запускаючи процес утворення інвадоподій. На більш пізніх етапах TKS5 регулює реорганізацію актинового цитоскелету та деградацію позаклітинного матриксу. TKS5 також регулює продукцію ROS, які $є$ важливими регуляторами сигналів різноманітних клітинних функцій

Кл юч о в і с л о в а: TKS5, інтерактом, інвадоподія, скафолдний білок.

\section{Интерактом скаффолдного белка инвадоподий TKS5}

С. В. Кропивко

TKS5 скаффолдный белок, который принимает участие в функционировании инвадоподий и продукции активных форм кислорода (ROS). TKS5 критически важный компонент инвадоподий поскольку при его отсутствии раковые клетки утрачивают возможность образовывать эти структуры инвазивности. Он фосфорилируется SRC-киназой в следствии чего взаимодействует с фосфотидилинозитид фосфатами мембраны запуская процесс образования инвадоподий. На более поздних этапах TKS5 регулирует реорганизацию актинового цитоскелета и деградацию внеклеточного матрикса. TKS5 также регулирует продукцию ROS, которые являются важными регуляторами сигналов разнообразных клеточных функцій.

Кл ючевы е слов а: TKS5, интерактом, инвадоподия, скаффолдный белок.

Received 10.10.2015 